\section{Assessment of human health risk from organochlorine pesticide residues in Cidade dos Meninos, Duque de Caxias, Rio de Janeiro, Brazil}

\author{
Avaliação de risco à saúde humana por resíduos \\ de pesticidas organoclorados em Cidade dos \\ Meninos, Duque de Caxias, Rio de Janeiro, Brasil
}

\author{
${ }^{1}$ Núcleo de Estudos em \\ Saúde Coletiva, Universidade \\ Federal do Rio de Janeiro, \\ Rio de Janeiro, Brasil. \\ 2 Secretaria de Vigilância em \\ Saúde, Ministério da Saúde, \\ Brasília, Brasil. \\ 3 AMBIOS Engenharia e \\ Processos Ltda., São Paulo, \\ Brasil. \\ Correspondence \\ C. I. R. F. Asmus \\ Núcleo de Estudos em Saúde \\ Coletiva, Universidade \\ Federal do Rio de Janeiro. \\ Av. Brigadeiro Trompowski \\ $s / n$, Pça da Prefeitura da \\ Cidade Universitária, \\ Rio de Janeiro, $R J$ \\ 21949-900, Brasil. \\ carmenfroes@nesc.ufrj.br
}

\section{Abstract}

This article presents the results of a heath risk assessment in Cidade dos Meninos, an area contaminated with organochlorine pesticide residues located in the county (municipality) of Duque de Caxias, Rio de Janeiro State, Brazil. The Agency for Toxic Substances and Disease Registry (ATSDR) risk assessment methodology was applied. The following organochlorine compounds exceeded the established limits and were considered target pollutants: $\mathrm{HCH}$ and its isomers (in eggs, milk, and soil); DDT and its metabolites; trichlorobenzenes; trichlorophenols; dioxins and furans (eggs and soil). For all the substances studied (with the exception of trichlorophenols), the estimated doses exceeded the minimum risk levels for chronically exposed children and adults. According to the ATSDR classification, the area was considered an "urgent public health hazard" because of its high and serious exposure to substances that are dangerous to human health.

Organochlorine Insecticides; Environmental Pollution; Envimental Risks; Risk Assessment
Carmen Ildes R. Fróes Asmus ${ }^{1}$

Herling Gregorio Aguilar Alonzo 2

Marisa Palácios 1

Alexandre Pessoa da Silva ${ }^{3}$

Maria Isabel de Freitas Filhote 1

Daniela Buosi 2

Volney de Magalhães Câmara ${ }^{1}$

\section{Introduction}

One of the most negative consequences of industrial development in the world has been the disposal of residues that are potentially hazardous to human health. The United States produces some 40 million tons of hazardous waste per year 1 . In Brazil, an investigation conducted by the Ministry of Health and covering the years 2001 to 2004 identified 15,237 areas with contaminated soil, of which 11,458 are areas for the final disposal of urban waste, in addition to 3,769 others, including industrial waste and pesticide deposits 2 . Contamination of these areas results in exposure to toxic substances for the resident populations, leading to harmful effects for health. Health institutions and professionals frequently need to characterize the health risk for these populations, and various methodologies have been proposed for this purpose.

The health risk assessment methodology for exposure to hazardous residues developed by the U.S. Agency for Toxic Substances and Disease Registry (ATSDR) ${ }^{3}$ defines as objects for assessment: chemical compounds, elements, or combinations which due to their amount, concentration, and physical or toxicological characteristics can pose an immediate or potential hazard to human health or the environment, when inadequately used, treated, stored, transported, or disposed. The principal examples for use in 
Brazil include residues from industrial processes and urban waste deposits.

Cidade dos Meninos is located in the county (municipality) of Duque de Caxias in the Baixada Fluminense area, Rio de Janeiro State, Brazil, where a factory was set up in 1950 for the production of hexachlorocyclohexane $(\mathrm{HCH})$ and formulation and storage of other pesticides, like trichloro-bis-(chlorophenyl)-ethane (DDT). The factory closed its operations in 1961, and the remaining production was stored in the open air in the immediate vicinity of the production unit 4 . This deposit was estimated at 350 tons of technical $\mathrm{HCH}$, plus other products used in its processing, in direct contact with the soil, in a barren area measuring approximately $13,000 \mathrm{~m}^{2}$. An attempt at remediation was made in 1995, using calcium oxide (quicklime), mixed with the residues and incorporated into the soil by mechanical processes. The attempt was unsuccessful, leading to a mass of some 29.7 thousand tons of contaminated material and expansion of the principal focus of contamination to an area of $38,000 \mathrm{~m}^{2}$

In 2001, the Ministry of Health, through the Pan-American Health Organization, hired a team of specialists and researchers from the company AMBIOS Engenharia e Processos Ltda., in partnership with the Núcleo de Estudos em Saúde Coletiva, Universidade Federal do Rio de Janeiro [Nucleus for Public Health Studies at the Federal University in Rio de Janeiro], to conduct a human health risk assessment based on the ATSDR methodology. The final report from this study was submitted to the Ministry of Health in April 2002 5. The current article aims to present the results, based on the application of this methodology in the area known as Cidade dos Meninos.

\section{Methodology}

Application of the ATSDR risk assessment methodology included all of its proposed stages: survey of the risk area's history, identification of the population's health concerns, characterization of the environmental contamination process, and establishment of health implications. The complete process allowed: classifying the site's public health hazard level; elaborating conclusions and recommendations for health and for future environmental studies; and identifying the necessary measures to mitigate or prevent adverse health effects 6 .

Assessment of the site information included the customary description of the site and its historical aspects, a survey of the demographic data and living, work, and health conditions of the lo- cal population. The above assessment was based on an analysis of all the studies performed as of 2001, made available by the Ministry of Health 5 . The population's health concerns were identified by daily site visits, meetings with representatives of the neighborhood association, and interviews with other community leaders.

Due to the limited amount of data on environmental dispersal of the contaminants outside the focus areas and the lack of data covering all the target contaminants, samples were taken of the topsoil and foods (eggs) for analysis of the contaminant levels. The soil sampling was systematic, using a grid starting from two imaginary straight lines, located respectively 50 and $100 \mathrm{~m}$ from the shoulders of the Camboaba Road. The sampling points were set at $500 \mathrm{~m}$ from these straight lines, using as the starting point the principal sentry house for Cidade dos Meninos. In addition to the sampling points on the proposed grid, sampling points were established in the immediate vicinity of the houses along the branch of the Camboaba road leading to the Olaria and Lixão areas, situated inside Cidade dos Meninos.

Concentration data for each contaminant detected in the soil samples in the principal emission foci in Cidade dos Meninos were compared to the reference values for Dutch legislation for residential soils (MRT - maximum risk tolerance - and intervention value) 7 . The tests were performed by a private laboratory from Rio de Janeiro (method's detection limit: $0.01 \mu \mathrm{g} / \mathrm{kg}$ for all the compounds analyzed; o,p'DDE, o,p'DDD, and o,p'DDT were quantified by the semi-quantitative method).

In relation to foods, eggs were chosen because they are large bioconcentrators of organochlorine pesticides, and together with cow's milk constitute a basic source of animal protein for local residents. One egg each was collected from all the houses where chickens were raised, totaling 22 eggs. Figure 1 shows a spatial distribution map of the samples collected in Cidade dos Meninos. The pesticide levels in milk samples from cows raised in Cidade dos Meninos and used to calculate the exposure dose in foods were determined by Mello 8 in her Master's thesis. Sample collection was done with the dairy farmers located at the time of the studies. Each sample was a composite of the daily production for each farmer. The samples thus came from the dairy herds that grazed freely throughout the entire Cidade dos Meninos area.

The pesticide analyses of the food samples were conducted by a private laboratory from Rio de Janeiro (method's detection limit: $0.01 \mu \mathrm{g} / \mathrm{kg}$ for all the compounds analyzed; o,p'DDE, o,p'DDD, and $o, p^{\prime}$ DDT were quantified by the semi-quanti- 
Figure 1

Graphic representation of households where sample chicken eggs were collected, and concentrations of target pollutants. Cidade dos Meninos, Duque de Caxias, Rio de Janeiro, Brazil, 2002

CONCENTRATIONS STRIPS

$$
\begin{aligned}
& \text { 0-100 ppb } \\
& \text { 100-1000 ppb }
\end{aligned}
$$$$
>1000 \mathrm{ppb}
$$

Georeferenced dwellings in Cidade dos Meninos

9 Households where chicken eggs were collected
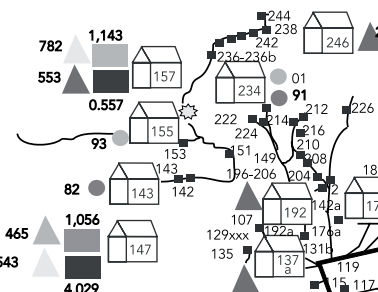

210
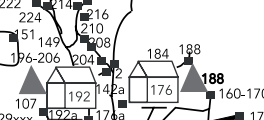

172

$186=119$
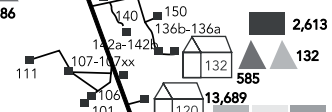

$55 \quad \begin{array}{llll}120 & 16 & 1,356 & 1,036\end{array}$
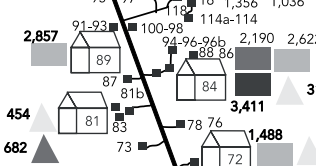

682

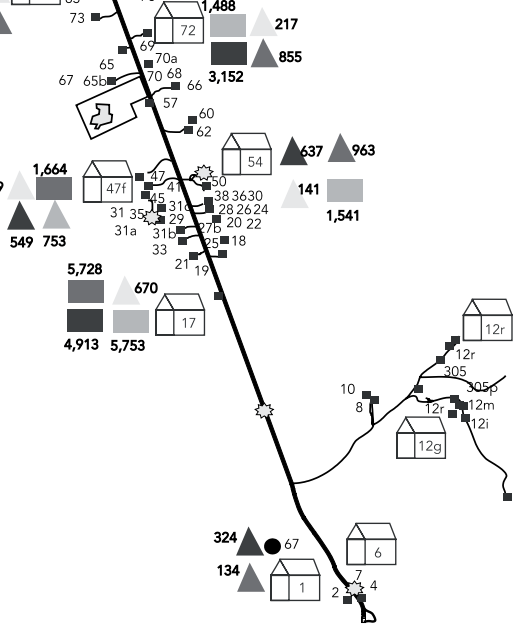

COMPOUNDS

Alpha-H

o,p-DDT

$p, p-D D E$

Beta-H

$p, p-D D D$

1,2,4-trichlorobenzene tative method). The pesticide residue levels in the foods were compared to the maximum residue levels set by the European Food Safety Authority (EFSA) 7, considered the most complete and rigorous international standard.

Selection of the target contaminants was based on comparison with the maximum concentrations detected for each contaminant in each environmental compartment analyzed, that is, the worst scenario for each, considering the toxicity of the respective compounds and the precautionary criterion.

The exposure doses were estimated based on the concentrations of contaminants found in the environmental compartments. All the environmental media would have to be considered for 
this purpose (water, soil, air, and foods), as well as all the exposure routes (inhalatory, oral, dermal, and mucosal). However, estimation of the exposure doses in Cidade dos Meninos did not consider exposure through water and air. At the time, there were no conclusive studies on either the groundwater contamination plume or reliable information on consumption of well water in the area or contamination of the 31 existing wells in Cidade dos Meninos. Meanwhile, respiratory exposure due to inhalation of particulate matter (suspended dust from the road, with the movement of pedestrians and various forms of transportation) was frequent due to the circulation especially of women and children on the road (surface soil), where secondary foci were identified. The Department of Science and Technology under the Ministry of Health ${ }^{9}$ conducted an analysis of samples of household dust and identified human exposure to the organochlorine compounds found in this material, even in households farther from the principal focus. However, the qualitative characteristics of the methodology employed 10, although efficient in the identification of the contaminated households, did not allow estimating the exposure of residents. Therefore, estimation of population exposure used only the results of the residue analyses for soil and food samples.

The entire population was considered potentially exposed, because everyone has contact with the soil and eats the food produced in the area. Two age brackets were determined to estimate the exposure dose: 11 years or younger, considering a mean body weight of $30 \mathrm{~kg}$, and 12 years and older, considering a mean body weight of $70 \mathrm{~kg}$. This also required calculating the food consumption and frequency and duration of exposure. Intake was estimated assuming one egg a day and 100g of milk for adults and 200g for children (one glass). Exposure was considered to be continuous, throughout life.

The exposure doses were estimated for the contaminants present in the soil (ingestion) and foods (ingestion) using the following formulas 6 .

\section{Estimated dose from soil ingestion (EDsi)$$
\mathrm{Edsi}=\underline{\mathrm{C} \times \mathrm{IR} \times \mathrm{EF} 10^{-6}}
$$$$
\text { BW }
$$

where, $\mathrm{C}=$ concentration of contaminant in topsoil $(\mathrm{mg} / \mathrm{kg})$; IR = soil ingestion rate; $\mathrm{EF}=$ exposure factor; BW = body weight. Standard values (ATSDR): adults $-50 \mathrm{mg} /$ day; children -50 to 200mg/day (normal children, without appetite disorders common in children up to three years of age and from low-income families).

\section{Estimated ingestion dose from contaminated foods (EDf)

$$
\mathrm{Edf}=\Sigma_{\mathrm{i}=1}^{\mathrm{n}} \frac{\mathrm{C}_{\mathrm{i}} \times \mathrm{Ri}_{\mathrm{i}} \times \mathrm{EF}}{\mathrm{BW}}
$$

where, $\mathrm{C}=$ concentration of contaminant in food group $\mathrm{i}(\mathrm{mg} / \mathrm{g})$; $\mathrm{Ri}=$ intake rate for food group $\mathrm{i}$ (g/day); $\mathrm{EF}$ = exposure factor; $\mathrm{BW}=$ body weight.

The estimated doses were then compared to parameters indicating the level of health risk. For the risk of non-carcinogenic effects, the ATSDR minimum risk level 11 and Environmental Protection Agency reference dose 12 were used as indicators

The minimum risk level is based on the highest dose at which no adverse health effect is observed, obtained through experimental studies in animals (NOAEL, no observed adverse effect level) for chronic exposure. Taking alpha-HCH as an example for the occurrence of hepatic nodules in male rats fed orally, a NOAEL of $0.8 \mathrm{mg}$ / kg-day and an uncertainty factor of 100 (10 for interspecies extrapolation and 10 for intraspecies variations) yield a minimum risk level of $0.008 \mathrm{mg} / \mathrm{kg}$-day.

Calculation of the risk of carcinogenic effects used the slope factor 13 to estimate the excess cancer risk for each substance, based on estimated exposure. This calculation was obtained by adding all the risks for individual contaminants, based on calculation of lifetime exposure for each contaminant. Taking alpha-HCH as an example, assuming an estimated dose of $0.541 \mu \mathrm{g} / \mathrm{kg} /$ day up to 11 years and $0.12 \mu \mathrm{g} / \mathrm{kg} /$ day from 12 to 70 years (taking 70 years as the mean lifespan) yields an estimated lifetime exposure of $0.188 \mu \mathrm{g} / \mathrm{kg} /$ day (total daily childhood dose x 12 years plus total daily adult dose $\mathrm{x} 58$ years, divided by 70 to obtain the weighted mean). The resulting dose is converted to $\mathrm{mg} / \mathrm{kg}$ and multiplied by the corresponding slope factor 14 .

\section{Results}

\section{Socio-demographic characterization}

Cidade dos Meninos is characterized by poverty and lack of urban infrastructure, with large landholdings for growing sugar cane, manioc, and vegetables and livestock operations like swine and beef and dairy cattle. There is electricity, but no sewage or garbage disposal, and the local residents have the habit of burning their household waste. An analysis of the Family Health Program registry 15 showed a total of 1,199 individuals (594 females and 605 males). Considering the existence of additional risks due to the presence of pesticide residues, the most relevant age groups 
were the following: < 1 year, 19 (1.6\%); 1-4 years, 115 (9.6\%); 5-14 years, 212 (18.5\%); women 15-34 years of age, 190 (33.4\%); and > 65 years, $83(7 \%)$.

\section{Environmental data}

The vast majority of residents in Cidade dos Meninos live alongside the Camboaba Road and its local branches. Camboaba Road has long stretches with secondary foci of pesticide residue contamination, especially the stretch from the main entrance on Avenida Presidente Kennedy to the proximities of the principal focus. This stretch crosses Vila Malária, an area with numerous households. Table 1 shows the concentrations of target contaminants in the principal contamination focus and the most important secondary foci.

During the visits and interviews with local residents, the team observed livestock grazing in the surrounding pastures and pigs rooting and chickens pecking in the backyards. Table 2 shows the target contaminants found in eggs from Cidade dos Meninos.

The following organochlorine compounds exceeded the established standards and were considered target contaminants to be observed in the monitoring and remediation processes and in the health follow-up studies on the affected populations: $\mathrm{HCH}$ and its isomers (eggs, milk, soil); DDT and its metabolites (eggs, milk, soil); trichlorobenzenes (soil); trichlorophenols (soil); dioxins and furans (eggs, soil).

\section{Toxicological assessment}

Tables 3 and 4 show the estimated exposure doses of contaminants via ingestion of soil and eggs. Similar calculations were done for milk.

In Cidade dos Meninos, exposures to DDT and dioxin exceed the acute, intermediate, and chronic minimum risk levels. For HCH isomers, the acute and chronic minimum risk levels are exceeded by the estimated exposure dose in children.

Table 5 shows the oral exposure doses for the target population groups that exceed the minimum risk level and the calculated excess risk for non-carcinogenic effects.

Table 6 shows the calculated excess cancer risk for children and adults in Cidade dos Meninos, using the estimated exposure doses ( $\mu \mathrm{g} / \mathrm{kg}$-day) and the dose-response slope factor for cancer, the result of which was 0.024 for the set of target contaminants.

\section{Health data}

There are no records on overall and specific mortality, infant mortality (neonatal and late), maternal mortality, cancer incidence, birth defects, or the principal causes of hospitalization for the population in Cidade dos Meninos 16.

In the health survey done as part of the risk assessment, 21\% (59/281) of interviewees reported some health problem, but no specific pattern was found. Importantly, the miscarriage rate in females over 12 years of age was $31 \%$ (28/90). No alterations were found in mean birth weight (3.1 kg) or mean gestational age (8.867 months) in the last pregnancy.

\section{Discussion}

This study identified the main active ingredients, the magnitude of environmental contamination, and the exposure routes for the population in $\mathrm{Ci}$ dade dos Meninos. Based on their presence in the topsoil, foods, wells, and air, these compounds can be absorbed by ingestion, skin contact, or inhalation. In addition to the principal focus, the study found secondary foci and inadequate use of residues (as household insecticide), leading to exposure to the target contaminants among the population in the study area.

The reference values come from animal studies extrapolated to humans, and in this case to the specific population in Cidade dos Meninos, which generates uncertainties. These uncertainties are of a general nature, present in any extrapolation, but in this case the specific uncertainties should also be analyzed. Estimated exposure based on environmental concentration data raised doubts because of the limited number of samples from the contaminated site, and the highest concentration found in the samples was used.

Other uncertainties were related to the consumption of contaminated foods in Cidade dos Meninos. There were doubts on this information, because during the interviews the residents appeared afraid to lose their place of living. Estimated consumption was based on information about farm animals $\mathrm{HCH}$ concentrates in adipose tissue, and $33 \%$ of the families raised chickens).

The ideal situation would be to calculate individual food consumption, but since this was impossible, the study worked with possible exposure scenarios. Exposure estimation considered only milk and eggs. This is certainly not the worst scenario, but animal fat (e.g., lard) should also be considered; although it was not quantified, the concentration is probably also high. Importantly, 
Table 1

Pesticide concentrations in soils in principal pollutant emission foci and reference values for soils ( $\mu \mathrm{g} / \mathrm{kg}$ ). Cidade dos Meninos, Duque de Caxias, Rio de Janeiro State, Brazil, 2002.

\begin{tabular}{|c|c|c|c|c|c|c|c|}
\hline \multirow[t]{2}{*}{ Compound } & \multicolumn{2}{|c|}{ Principal focus } & \multicolumn{2}{|c|}{ Camboada Road } & \multicolumn{3}{|c|}{ Reference values } \\
\hline & Maximum & Mean & Maximum & Mean & MTR & Intervention * & EMEG $(\mathrm{mg} / \mathrm{kg})$ \\
\hline $1,2,4-\mathrm{TCB}$ & 4,001 & 564 & 390 & 95 & & 30,000 & 20 \\
\hline $2,4,6-\mathrm{TCF}$ & 220 & 51 & 1,742 & 174,9 & & & 150 \\
\hline $2,4,5-\mathrm{TCF}$ & 19 & 5,35 & 120 & 18,7 & & & 150 \\
\hline Alpha-HCH & 89,467 & 15,456 & $1,104,293$ & 224,344 & 290 & 2,000 & 400 \\
\hline $\mathrm{HCH}$ & 0 & 0 & 0 & 0 & & & \\
\hline Beta-HCH & 45,429 & 1,0249 & 242,149 & 24,302 & 920 & 2,000 & 30 \\
\hline Gamma-HCH & 32,244 & 10,080 & 109,564 & 10,983 & 230 & 2,000 & 5 \\
\hline Delta-HCH & 22,270 & 4008 & 32,871 & 3,312 & & 2,000 & \\
\hline PCF & 7 & 0 & 6 & 1 & & 5,000 & 50 \\
\hline o,p-DDE & 17 & 3 & 3 & 1 & 9 & 4,000 & \\
\hline$p, p-D D E$ & 393 & 89 & 95 & 16 & 9 & 4,000 & \\
\hline o,p-DDD & 124 & 24 & 10 & 2 & 9 & 4,000 & \\
\hline$p, p-D D D$ & 627 & 105 & 52 & 10 & 9 & 4,000 & \\
\hline o,p-DDT & 242 & 58 & 235 & 38 & 9 & 4,000 & \\
\hline $\mathrm{p}, \mathrm{p}-\mathrm{DDT}$ & 1,095 & 246 & 932 & 143 & 9 & 4,000 & 25 \\
\hline Dioxins & \multicolumn{2}{|c|}{ maximum: 13,900 ppt. } & & & & 1,000 ppt. & 50,000 ppt. \\
\hline
\end{tabular}

MTR: maximum tolerable risk 7; EMEG: Environmental Media Evaluation Guides 3; ppt.: parts per trillion.

* Intervention value 7 .

Maximum concentrations of organochlorine compounds measured in eggs, and reference values used. Cidade dos Meninos, Duque de Caxias, Rio de Janeiro State, Brazil, 2002.

\begin{tabular}{lcc}
\hline Compound & Maximum concentration in chicken eggs & Reference values \\
\hline Trichlorobenzenes & $1.356 \mu \mathrm{g} / \mathrm{kg}$ & \\
Trichlorophenols & $\mathrm{ND}$ & \\
Alpha-HCH & $66 \mu \mathrm{g} / \mathrm{kg}$ & $20 \mu \mathrm{g} / \mathrm{kg}$ * \\
Beta-HCH & $4.913 \mu \mathrm{g} / \mathrm{kg}$ & $101 \mu \mathrm{g} / \mathrm{kg}$ * \\
Gamma-HCH & $\mathrm{ND}$ & $10 \mu \mathrm{g} / \mathrm{kg}$ * \\
Pentachlorophenol & $\mathrm{ND}$ & \\
Hexachlorobenzene & $\mathrm{ND}$ & $20 \mu \mathrm{g} / \mathrm{kg}$ * \\
DDE & $13.689 \mu \mathrm{g} / \mathrm{kg}$ & $50 \mu \mathrm{g} / \mathrm{kg}$ * \\
DDD & $1.097 \mu \mathrm{g} / \mathrm{kg}$ & $50 \mu \mathrm{g} / \mathrm{kg}$ * \\
DDT & $5.728 \mu \mathrm{gg} / \mathrm{kg}$ & $50 \mu \mathrm{g} / \mathrm{kg}$ * \\
Dioxins and furans & $30 \mathrm{ng}$ WHO-PCDD/F-TEQ/kg fat & $3 \mathrm{ng} \mathrm{WHO-PCDD} / \mathrm{F}-\mathrm{TEQ} / \mathrm{kg}$ fat
\end{tabular}

* Maximum residue levels 7 .

these calculations underestimate exposure to the target contaminants in Cidade dos Meninos, since the exposure doses were not measured for all the foods produced and consumed or for all the contaminated environmental compartments.
Dermal exposure doses (human body contact with contaminated soil and dust) were not included in the final exposure calculation for two reasons: (1) the international literature review only yielded the bioavailability factor for $\mathrm{HCH}$, which served as the basis for calculating the oth- 
Estimated exposure dose from ingestion of soil contaminated with organochlorines. Cidade dos Meninos, Duque de Caxias, Rio de Janeiro State, Brazil, 2002.

\begin{tabular}{|c|c|c|c|c|c|c|c|c|c|c|c|}
\hline Compound & $\begin{array}{l}\text { Concen- } \\
\text { tration * }\end{array}$ & $\begin{array}{l}\text { IR (chil- } \\
\text { dren) ** }\end{array}$ & $\begin{array}{l}\text { IR (adul- } \\
\text { ts) } \star \star \star \star\end{array}$ & $\begin{array}{l}\text { EF (chil- } \\
\text { dren) \# }\end{array}$ & $\begin{array}{c}\text { EF (adul- } \\
\text { ts) \# }\end{array}$ & $\begin{array}{l}\text { BW (chil- } \\
\text { dren) \#\# }\end{array}$ & $\begin{array}{l}\text { BW (chil- } \\
\text { dren) \#\#\# }\end{array}$ & $\begin{array}{c}\text { BW (adul- } \\
\text { ts) } \S\end{array}$ & $\begin{array}{l}\text { ED (chil- } \\
\text { dren) §§ }\end{array}$ & $\begin{array}{l}\text { ED (chil- } \\
\text { dren) } \S \S \S\end{array}$ & $\begin{array}{c}\text { ED (adul- } \\
\text { ts) }{ }^{\dagger}\end{array}$ \\
\hline Alpha-HCH & 29 & 0.2 & 0.05 & 1 & 1 & 10 & 30 & 70 & 0.58 & 0.19 & 0.02 \\
\hline Beta-HCH & 91 & 0.2 & 0.05 & 1 & 1 & 10 & 30 & 70 & 1.82 & 0.61 & 0.07 \\
\hline Gamma-HCH & 3 & 0.2 & 0.05 & 1 & 1 & 10 & 30 & 70 & 0.06 & 0.02 & 0.00 \\
\hline Delta-HCH & 3 & 0.2 & 0.05 & 1 & 1 & 10 & 30 & 70 & 0.06 & 0.02 & 0.00 \\
\hline o,p-DDE & 7 & 0.2 & 0.05 & 1 & 1 & 10 & 30 & 70 & 0.14 & 0.05 & 0.01 \\
\hline$p, p-D D E$ & 64 & 0.2 & 0.05 & 1 & 1 & 10 & 30 & 70 & 1.28 & 0.43 & 0.05 \\
\hline o,p-DDD & 3 & 0.2 & 0.05 & 1 & 1 & 10 & 30 & 70 & 0.06 & 0.02 & 0.00 \\
\hline$p, p-D D D$ & 17 & 0.2 & 0.05 & 1 & 1 & 10 & 30 & 70 & 0.34 & 0.11 & 0.01 \\
\hline o,p-DDT & 6 & 0.2 & 0.05 & 1 & 1 & 10 & 30 & 70 & 0.12 & 0.04 & 0.00 \\
\hline$p, p-D D T$ & 19 & 0.2 & 0.05 & 1 & 1 & 10 & 30 & 70 & 0.38 & 0.13 & 0.01 \\
\hline 2,4,6-trichlorophenol & 37 & 0.2 & 0.05 & 1 & 1 & 10 & 30 & 70 & 0.74 & 0.25 & 0.03 \\
\hline 2,4,5-trichlorophenol & 0 & 0.2 & 0.05 & 1 & 1 & 10 & 30 & 70 & 0.00 & 0.00 & 0.00 \\
\hline 3,4,5-trichlorophenol & 4 & 0.2 & 0.05 & 1 & 1 & 10 & 30 & 70 & 0.08 & 0.03 & 0.00 \\
\hline 2,3,5,6-tetrachlorophenol & 27 & 0.2 & 0.05 & 1 & 1 & 10 & 30 & 70 & 0.54 & 0.18 & 0.02 \\
\hline 2,3,4,5-tetrachlorophenol & 17 & 0.2 & 0.05 & 1 & 1 & 10 & 30 & 70 & 0.34 & 0.11 & 0.01 \\
\hline Pentachlorophenol & 26 & 0.2 & 0.05 & 1 & 1 & 10 & 30 & 70 & 0.52 & 0.17 & 0.02 \\
\hline Hexachlorobenzene & 2 & 0.2 & 0.05 & 1 & 1 & 10 & 30 & 70 & 0.04 & 0.01 & 0.00 \\
\hline Total dioxins + furans & $5.4296 \mathrm{tt}$ & 0.2 & 0.05 & 1 & 1 & 10 & 30 & 70 & 0.1086 & 0.0362 & 0.0039 \\
\hline
\end{tabular}

IR: ingestion rate; EF: exposure factor; BW: body weight; ED: exposure dose.

* Pesticide concentration in $\mathrm{ppb}(\mu \mathrm{g} / \mathrm{Kg})$ in topsoil samples 5 ;

** Soil ingestion rate for children $=200 \mathrm{mg} /$ day (upper standard value for age bracket up to 11 years 3 ;

$\star \star \star$ Soil ingestion rate for adults $=50 \mathrm{mg} /$ day 3 ;

\# Exposure factor, assuming continuous exposure;

\#\# Standard body weight for children up to 1 year of age 3;

\#\#\# Standard body weight for children from 1 to 11 years 3 ;

$\S$ Standard adult body weight (50th percentile) 3;

$\S \S$ Exposure dose from ingestion of contaminated soil, assuming a child with body weight of $10 \mathrm{~kg}(\mu \mathrm{g} / \mathrm{kg}$-day);

$\S \S \S$ Exposure dose from ingestion of contaminated soil, assuming a child with body weight of $30 \mathrm{~kg}(\mu \mathrm{g} / \mathrm{kg}-\mathrm{day})$;

† Exposure dose from ingestion of contaminated soil, assuming an adult with body weight of 70kg living in Cidade dos Meninos ( $\mu$ g/kg-day);

t† Concentration of total dioxins plus furans in toxic equivalents (TEQ).

er contaminants, thus leaving a large uncertainty factor and (2) because the international literature also failed to provide either risk indicators for dermal exposure or, consequently, parameters to compare the results.

In order to consider the worst scenario, since the compounds are interrelated and have synergic effects (although with different degrees of toxicity), it is possible to compare the sum of all the isomers with the minimum chronic exposure risk level. Importantly, the estimated oral exposure doses exceed the minimum risk level for short-term exposure (for gamma-HCH, but not for beta-HCH), intermediate exposure, and longterm (chronic) exposure.

For DDT, DDD, and DDE, the NOAEL parameter was also used for intermediate exposure to
DDT. A NOAEL of $0.05 \mathrm{mg} / \mathrm{kg}$-day and uncertainty factor of 100 (10 for interspecies extrapolation and 10 for intraspecies variation) yields a minimum risk level of $0.00005 \mathrm{mg} / \mathrm{kg}$-day. In order to consider the worst situation, the sum of all the metabolites was compared with the minimum intermediate risk level, given that they have synergic effects, even with different toxicities.

Importantly, the estimated exposure doses for dioxins exceed the minimum risk level for children by more than 100 thousand times. The reference values pertain to experiments with low doses and long duration (chronic), similar to the situation in Cidade dos Meninos. In addition, the exposure exceeded the acute and intermediate minimum risk levels, thus demonstrating the need for urgent intervention. 
Estimated exposure dose from ingestion of eggs contaminated with organochlorines. Cidade dos Meninos, Duque de Caxias, Rio de Janeiro State, Brazil, 2002.

\begin{tabular}{|c|c|c|c|c|c|c|c|c|c|}
\hline Compounds & $\begin{array}{l}\text { Concen- } \\
\text { tration * }\end{array}$ & $\begin{array}{l}\text { IR (chil- } \\
\text { dren) ** }\end{array}$ & $\begin{array}{l}\text { IR (adul- } \\
\text { ts) } \star \star \star\end{array}$ & $\begin{array}{c}\text { EF (chil- } \\
\text { dren) }\end{array}$ & EF (adults) & $\begin{array}{c}\text { BW (chil- } \\
\text { dren) \# }\end{array}$ & $\begin{array}{c}\text { BW (adul- } \\
\text { ts) \#\# }\end{array}$ & $\begin{array}{l}\text { ED (chil- } \\
\text { dren) \#\#\# }\end{array}$ & ED (adults) § \\
\hline Alpha-HCH & 66.69 & 0.055 & 0.055 & 1 & 1 & 30 & 70 & 0.1223 & 0.0524 \\
\hline Beta-HCH & 8557.4 & 0.055 & 0.055 & 1 & 1 & 30 & 70 & 15.6886 & 6.7237 \\
\hline$p, p-D D E$ & 13689 & 0.055 & 0.055 & 1 & 1 & 30 & 70 & 25.0968 & 10.7558 \\
\hline o.p-DDD & 16.76 & 0.055 & 0.055 & 1 & 1 & 30 & 70 & 0.0307 & 0.0132 \\
\hline$p, p-D D D$ & 1096.9 & 0.055 & 0.055 & 1 & 1 & 30 & 70 & 2.0111 & 0.8619 \\
\hline o,p-DDT & 572806 & 0.055 & 0.055 & 1 & 1 & 30 & 70 & 10.5025 & 4.5011 \\
\hline 1,2,4-trichlorobenzene & 1356 & 0.055 & 0.055 & 1 & 1 & 30 & 70 & 2.4860 & 1.0654 \\
\hline Total dioxins + furans & $36.2849 \S \S$ & 0.055 & 0.055 & 1 & 1 & 30 & 70 & 0.0665 & 0.0285 \\
\hline
\end{tabular}

IR: ingestion; EF: exposure factor; BW: body weight; ED: exposure dose.

* Pesticide concentration in ppb $(\mu \mathrm{g} / \mathrm{Kg})$ in topsoil samples 5 ;

** Egg ingestion rate for children $=0.055 \mathrm{~kg} /$ day (estimated ingestion of 1 egg per day);

*** Egg ingestion rate for adults $=0.055 \mathrm{~kg} /$ day (estimated ingestion of 1 egg per day);

\# Standard body weight (50th percentile) for children up to 11 years 3;

\#\# Standard adult body weight (50th percentile) 3;

\#\#\# Exposure dose from ingestion of contaminated food (eggs), assuming a child with $30 \mathrm{~kg}$ body weight ( $\mu \mathrm{g} / \mathrm{kg}$-day);

$\S$ Exposure dose from ingestion of contaminated food (eggs), assuming an adult weighing $70 \mathrm{~kg}$ and living in Cidade dos Meninos ( $\mu \mathrm{g} / \mathrm{kg}$-day);

$\S \S \mathrm{TEQ}$, sample collected, 5 eggs.

Importantly, for all the compounds studied except for trichlorophenols (chronic exposure), the estimated doses exceed the minimum risk levels for children and adults, thus demonstrating the magnitude of exposure in Cidade dos Meninos.

The chemical compounds found are highly fat-soluble, i.e., easily absorbed by the body and concentrated in adipose tissues. This important characteristic allows the confirmation of high concentration in animal food sources (eggs and milk), consumed at relatively high proportions in the community. The fact that they are fat-soluble facilitates their absorption by the stomach and especially the intestine. Likewise, the results in water and soil suggest the possible absorption of these compounds through other environmental compartments, facilitated by their lipophilic characteristics.

According to the international literature $17,18,19,20,21,22$, the principal non-carcinogenic effects of these compounds are observed in the liver and central nervous and reproductive systems. A study on seven families in Cidade dos Meninos 23 showed liver enzyme alterations, but the clinical history and laboratory tests did not rule out interference by other factors (like consumption of alcohol and other drugs) in these results. The miscarriage rate of $31 \%$ (28/90) in women over 12 years of age also called attention, but this figure requires further investigation, since data collection on this type of information is always difficult.

As for classification of the target contaminants' carcinogenicity, $\mathrm{HCH}$ and its isomers and DDT and its metabolites belong to the category of "possibly carcinogenic to humans", since $2,3,7,8$-TCDD (from the dioxins group) is classified as "carcinogenic to humans" 24 . For every carcinogenic substance, there is a risk of developing cancer at any dose different from zero. Thus, the $2.4 \%$ excess cancer shown in Table 6 generally means that one can expect that part of this population, namely 40 of the 1,660 inhabitants, could develop cancer due to exposure to these contaminants. Two cross-sectional studies 5,23 pointed to eight cancer cases without a specific pattern. Meanwhile, one of the major difficulties in studying the carcinogenicity of chemical substances is the scarcity of data in humans. For most of the agents, the existing information is extracted from data on animal experiments. To extrapolate these data to humans, it is necessary to observe that in addition to the differences between species, the experiments are done with doses of a single substance, with a specific absorption route, while most situations of human exposure actually involve multiple substances with different absorption routes 25 . 
Oral exposure doses for target sub-populations that exceed the minimum risk levels. Cidade dos Meninos, Duque de Caxias, Rio de Janeiro State, Brazil, 2002.

\begin{tabular}{|c|c|c|c|c|c|c|c|c|}
\hline \multirow[t]{4}{*}{ Compound } & \multirow[t]{4}{*}{$\begin{array}{l}\text { Exposure } \\
\text { route }\end{array}$} & \multicolumn{2}{|c|}{ Ingestion by all routes } & \multicolumn{2}{|c|}{$\begin{array}{l}\text { Reference value } \\
\text { for ingestion }\end{array}$} & \multirow{4}{*}{$\begin{array}{l}\text { Exceeded by } \\
\text { estimated } \\
\text { exposure } \\
\text { dose }\end{array}$} & \multirow{2}{*}{\multicolumn{2}{|c|}{$\begin{array}{c}\text { Demonstration of } \\
\text { excess risk for } \\
\text { non-carcinogenic } \\
\text { effects (ED/ Reference) * }\end{array}$}} \\
\hline & & \multirow[t]{3}{*}{ ED (children) } & \multirow[t]{3}{*}{ ED (adults) } & \multirow[t]{3}{*}{$\begin{array}{c}\text { Value } \\
\text { ( } \mu \mathrm{g} / \mathrm{kg} \text {-day) }\end{array}$} & \multirow[t]{3}{*}{ Source } & & & \\
\hline & & & & & & & ED/ & ED/ \\
\hline & & & & & & & $\begin{array}{l}\text { Reference } \\
\text { (children) }\end{array}$ & $\begin{array}{c}\text { Reference } \\
\text { (adults) }\end{array}$ \\
\hline Alpha-HCH & Topsoil, foods & 0.541195 & 0.12197 & 8.0 & MRL-C & No & - & - \\
\hline \multirow[t]{2}{*}{ Beta-HCH } & Topsoil, foods & 16.41422 & 6.814324 & 200.0 & MRL-A & No & & \\
\hline & & & & 0.6 & MRL-I & Yes & - & - \\
\hline \multirow[t]{2}{*}{ Gamma-HCH } & Topsoil & 0.020009 & 0.002149 & 10.0 & MRL-A & No & & \\
\hline & & & & 0.01 & MRL-I & Yes/No & - & - \\
\hline Delta- $\mathrm{HCH}$ & Topsoil & 0.020009 & 0.002149 & - & - & - & - & - \\
\hline \multirow[t]{3}{*}{$\Sigma \mathrm{HCH}^{*}$} & Topsoil, foods & 16.99543 & 6.940593 & 8.0 & MRL-A & Yes/No & & \\
\hline & & & & 10.0 & MRL-I & Yes/No & & \\
\hline & & & & 0.01 & MRL-C & Yes & $1,699.5$ & 694.1 \\
\hline \multirow[t]{3}{*}{$\Sigma * \star(D D T+D D D+D D E)$} & Topsoil, foods & 40.34582 & 17.67582 & 0.5 & MRL-A & Yes & & \\
\hline & & & & 0.5 & MRL-I & Yes & 80.7 & 35.4 \\
\hline & & & & 5.0 & IDA-WHO & Yes & & \\
\hline \multirow[t]{2}{*}{ Trichlorophenols ** } & Topsoil & 0.246773 & 0.02651 & 10 & MRL-A & No & & \\
\hline & & & & 3 & MRL-I & No & 0.1 & 0.0 \\
\hline \multirow[t]{3}{*}{ Dioxins } & Topsoil, foods & 0.118303 & 0.044345 & 0.0002 & MRL-A & Yes & & \\
\hline & & & & $2 \times 10-5$ & MRL-I & Yes & & \\
\hline & & & & $1 \times 10-6$ & MRL-C & Yes & $118,303.0$ & $44,345.0$ \\
\hline
\end{tabular}

ED: exposure dose; MRL-A: acute minimum risk level; MRL-C: chronic minimum risk level; MRL-I: intermediate minimum risk level.

* Used MRL derived from chronic exposure studies (> 1 year);

** Sum of concentrations of contaminants, and respective MRL.

Finally, the illness process is peculiar to each person, resulting from collective factors like the environment and the social, economic, historical, and cultural context in a given society. It is also determined by other factors of an individual nature, like each person's genetic map, the genetic legacy we inherit from our ancestors, and our body's nutritional status, development, and degree of maturity. The combination of these two orders of factors determines the relationship between health and disease in a person and explains why some fall ill and others do not, when exposed to chemical substances, and why different diseases can occur in persons exposed to the same compound.

Beyond the considerations on the need for research on the occurrence of health effects, there is the need for care for these populations, through training of technical personnel, development of specific protocols to treat cases of chemical contamination, continuing education programs with the community, and other measures to be conducted under the Sistema Único de Saúde [SUS; Unified National Health System]. Based on this premise, the Ministry of Health, through the Health Surveillance Secretariat, published the National Health Surveillance Program for Populations Exposed to Contaminated Soils 26 and the text Guidelines for the Elaboration of Surveillance and Health Care Protocols for Populations Exposed to Contaminated Soils 27, the objective of which is orient health actions to be developed with the affected populations. The two documents propose the organization of work groups with participation by the relevant Municipal, State, and Federal agencies, universities, and the community, to build a joint program for orienting health care activities for these populations. 
Table 6

Calculated excess cancer risk based on estimated exposure doses for adults and children in $\mu$ g/kg-day. Cidade dos Meninos, Duque de Caxias, Rio de Janeiro State, Brazil, 2002

\begin{tabular}{|c|c|c|c|c|c|}
\hline \multirow[t]{2}{*}{ Compound } & \multirow[t]{2}{*}{ Slope factor } & \multicolumn{2}{|c|}{ Estimated total daily dose ( $\mu \mathrm{g} / \mathrm{kg}$-day) } & \multirow{2}{*}{$\begin{array}{l}\text { Lifetime exposure } \\
\text { dose ( } \mu \mathrm{g} / \mathrm{kg} \text {-day) }\end{array}$} & \multirow[t]{2}{*}{ Lifetime excess risk } \\
\hline & & Children & Adults & & \\
\hline Alpha-HCH & 6.3 & 0.541195 & 0.12197 & 0.187848 & 0.001183 \\
\hline Beta-HCH & 1.8 & 16.41422 & 6.814324 & 8.322878 & 0.014981 \\
\hline Sum & & & & & 0.016165 \\
\hline DDT & 0.34 & 11.4828 & 5.14328 & 6.139491 & 0.002087 \\
\hline DDD & 0.24 & 3.133931 & 1.625079 & 1.862184 & 0.000447 \\
\hline DDE & 0.34 & 25.72909 & 10.90746 & 13.23657 & 0.0045 \\
\hline Sum & & & & & 0.007035 \\
\hline Trichlorophenols & 0.011 & 0.246773 & 0.02651 & 0.061123 & $6.72 \mathrm{E}-07$ \\
\hline Dioxins + furans & 6200 & 0.118303 & 0.044345 & 0.055967 & 0.000347 \\
\hline Total excess risk & & & & & 0.023547 \\
\hline
\end{tabular}

\section{Conclusion}

The human health risk assessment methodology for areas with hazardous residues is a powerful instrument to aid health managers in decisionmaking. After all the calculations, the results showed an estimate of the danger for the resident population in Cidade dos Meninos, both for the risk of cancer and the risk of systemic toxic effects. However, assessment of the effects of these chemical compounds on this population's health is still quite inconclusive. The results reflect the need to structure a health monitoring and in- formation system capable of generating reliable data on the affected population's health, progressively providing the elements for discussing the harm to human health caused by environmental contaminants.

To follow up on this population and offer the best treatment for all its health problems is an ethical commitment by the Brazilian Federal government. Finally, it is also important to highlight the need for legislation to support a national policy to identify and correct similar situations throughout Brazil's territory.

\section{Resumo}

Cidade dos Meninos é uma área localizada no Município de Duque de Caxias, Rio de Janeiro, Brasil, onde ocorreu contaminação ambiental por deposição de pesticidas organoclorados. Este artigo apresenta os resultados de um estudo de avaliação de risco para a saúde da população residente, utilizando-se a metodologia de avaliação de risco à saúde da Agency for Toxic Substances and Disease Registry. Os seguintes compostos organoclorados superaram as normas estabelecidas e foram considerados contaminantes de interesse: hexaclorociclohexano (HCH) e seus isômeros (ovo, leite, solo); tricloro-bis-(clorofenil)-etano (DDT) e seus metabólitos (ovo, leite, solo); triclorobenzenos (solo); triclorofenóis (solo); dioxinas e furanos (ovo, solo). Para todos os compostos estudados, exceto triclorofenóis, na situação de exposição crônica, as doses estimadas estavam acima dos níveis mínimos de risco à saúde, para crianças e adultos. A área foi classificada como de perigo urgente para a saúde pública por exposição de alta intensidade e grave a substâncias nocivas à saúde humana. Os autores observam que a realização de estudos de avaliação de risco para a saúde humana é uma importante ferramenta para a tomada de decisões para ações de saúde pública.

Inseticidas Organoclorados; Poluição Ambiental; Riscos Ambientais; Medição de Risco 


\section{Contributors}

C. I. R. F. Asmus wrote the manuscript and participated in all phases of the fieldwork and was responsible, in the corresponding report, for the section on implications for human health. V. M. Câmara and H. G. A. Alonzo participated in the critical analysis and correction of the manuscript. A. P. Silva coordinated the fieldwork and was responsible, in the corresponding report, for the section on environmental data. D. Buosi participated in the fieldwork and conducted the final reading of the text. M. I. F. Filhote and M. Palácios participated in the fieldwork and were responsible, in the corresponding report, for the sections on general community information and human health implications, respectively.

\section{References}

1. Environmental Protection Agency. Hazardous waste. http://www.epa.gov/ebtpages/wasthaz ardouswaste.html (accessed on 22/Sep/2006)

2. Ministério da Saúde. Identificação de populações sob risco de exposição e priorização de áreas com populações expostas a solo contaminado. http:// portal.saude.gov.br/portal/svs/visualizar_texto. cfm?idtxt=23900 (accessed on 19/Sep/2006).

3. Agency for Toxic Substances and Disease Registry. Public health assessment guidance manual. http://www.atsdr.cdc.gov/HAC/PHAManual/appg.html (accessed on 19/Sep/2006).

4. Ministério da Saúde. Atuação do Ministério da Saúde no caso de contaminação ambiental por pesticidas organoclorados, na Cidade dos Meninos, Município de Duque de Caxias, Rio de Janeiro. http://portal.saude.gov.br/portal/svs/visualizar_ texto.cfm?idtxt=23817 (accessed on 19/Sep/2006).

5. Ministério da Saúde. Avaliação de risco a saúde humana por resíduos de pesticidas organoclorados em Cidade dos Meninos, Duque de Caxias, RJ. http://portal.saude.gov.br/portal/svs/visualizar texto.cfm?idtxt=23560 (accessed on 19/Sep/2006).

6. Ministério da Saúde. Evaluación de riesgos en salud por la exposición a residuos peligrosos. http:// portal.saude.gov.br/portal/svs/visualizar_texto. cfm?idtxt=23807 (accessed on 19/Sep/2006).
7. European Food Safety Authority. Health and consumer protection directorate - general. Council directives: 76/895/EEC; 86/362/EEC; 86/363/EEC E 90/642/EEC. http://ec.europa.eu/food/plant/pro tection/pesticides/legislation_en.htm (accessed on 22/Sep/2006).

8. Mello JL. Avaliação da contaminação por $\mathrm{HCH}$ e DDT dos leites de vaca e humano provenientes da Cidade dos Meninos, Duque de Caxias-RJ. Rio de Janeiro [Masters Thesis]. Rio de Janeiro: Escola Nacional de Saúde Pública, Fundação Oswaldo Cruz; 1999.

9. Departamento de Ciência e Tecnologia em Saúde. Relatório sobre o trabalho de campo de vistorias domiciliares em Cidade dos Meninos - Duque de Caxias - RJ - para identificação de focos secundários de contaminação por pesticidas organoclorados. Brasília: Secretaria de Políticas de Saúde, Ministério da Saúde; 2001.

10. Silva AP, Câmara VM, Nascimento CM, Oliveira LJ, Silva E, Pivetta F, et al. Emissões de mercúrio na queima de amálgama: estudo da contaminação de ar, solos e poeira em domicílios de Poconé - MT. Tecnologia Ambiental 1996; 13:3-35.

11. Agency for Toxic Substances and Disease Registry. Minimal risk level. http://www.atsdr.cdc.gov/mrls. html (accessed on 15/May/2004). 
12. Environmental Protection Agency. Integrated risk information system: reference dose. http://www. epa.gov/iris/rfd.htm (accessed on 22/Sep/2006).

13. Environmental Protection Agency. Slope factor. http://www.epa.gov/IRIS/carcino.htm (accessed on 22/Sep/2006).

14. International Programme on Chemical Safety. General scientific principles of chemical safety. Geneva: World Health Organization; 2000. (Training Module, 4).

15. Departamento de Ciência e Tecnologia em Saúde. Cronologia de eventos relacionados a contaminação por HCH em “Cidade dos Meninos”, Duque de Caxias-RJ. Brasília: Secretaria de Políticas de Saúde, Ministério da Saúde; 2001.

16. Ministério da Saúde. Exposição humana a resíduos organoclorados na Cidade dos Meninos, Município de Duque de Caxias, Rio de Janeiro: relatório de trabalho da Comissão Técnica Assessora ao Ministério da Saúde. 2ạ Ed. Brasília: Ministério da Saúde; 2001.

17. Nunes MV, Tajara EH. Efeitos tardios dos praguicidas organoclorados no homem. Rev Saúde Pública 1998; 32:372-82.

18. D'Amato C, Torres JPM, Malm O. DDT (dicloro difenil tricloroetano): toxicidade e contaminação ambiental. Uma revisão. Química Nova 2002; 25:995-1002.

19. Agency for Toxic Substances and Disease Registry. Toxicological profile for DDT, DDE, DDD. http:// www.atsdr.cdc.gov/toxprofiles/tp35.html (accessed on 19/Sep/2006).

20. Agency for Toxic Substances and Disease Registry. Toxicological profile for chlorophenols. http:// www.atsdr.cdc.gov/toxprofiles/tp107.html (accessed on 19/Sep/2006).
21. Agency for Toxic Substances and Disease Registry. Toxicological profile for 2,3,7,8-tetrachlorod ibenzo-p-dioxin. http://www.atsdr.cdc.gov/toxpro files/tp104.html (accessed on 19/Sep/2006).

22. Agency for Toxic Substances and Disease Registry. Toxicological profile for alpha, beta, gamma, and delta-hexachlorocyclohexane. http://www.atsdr. cdc.gov/toxprofiles/tp43.html (accessed on 19/ Sep/2006).

23. Braga AMC. Contaminação ambiental por $\mathrm{HCH}$ em escolares na Cidade dos Meninos [Masters Thesis]. Rio de Janeiro: Escola Nacional de Saúde Pública, Fundação Oswaldo Cruz; 1996.

24. International Agency Research Cancer. Monographs on the evaluation of carcinogenic risks to humans. http://monographs.iarc.fr/ENG/Classifi cation/index.php (accessed on 22/Sep/2006).

25. International Agency Research Cancer. Studies of cancer in experimental animals. http://mono graphs.iarc.fr/ENG/Preamble/currentb3studies animals0706.php (accessed on 22/Sep/2006).

26 Ministério da Saúde. Programa nacional de vigilância em saúde de populações expostas a solos contaminados. http://portal.saude.gov.br/portal/ svs/visualizar_texto.cfm?idtxt=21567 (accessed on 22/Nov/2006).

27. Ministério da Saúde. Diretrizes para elaboração de protocolos de vigilância e atenção à saúde de populações expostas a solos contaminados. http:// portal.saude.gov.br/portal/svs/visualizar_texto. cfm?idtxt=21567 (accessed on 22/Nov/2006).

Submitted on 28/Sep/2006

Final version resubmitted on 04/Sep/2007

Approved on 05/Sep/2007 